\title{
FUNCTIONS OF THE IMAGE IN SHAPING THE TECHNICAL THINKING OF STUDENTS
}

\author{
Mariusz Śniadkowski', Agnieszka Jankowska² \\ 1 Fundamentals of Technology Faculty, Lublin University of Technology, 38 Nadbystrzycka Str., 20-618 Lublin, \\ Poland, e-mail:m.sniadkowski@pollub.pl \\ 2 Student of Lublin University of Technology, e-mail: aga.jankowska89@wp.pl
}

Received: 2014.09.25

Accepted: 2014.10.25

Published: 2014.12.01

\begin{abstract}
The world of technology can be a tool to support development processes, primarily cognitive, emotional and motivational. Adoption issues shaping the image function in the technical thinking of students is justified in many ways: a - impact on the development of human image; $b$ - multidimensional image and diversity of its media resources; $\mathrm{c}$ - the influence of the image on shaping the attitudes and behaviors of education; $\mathrm{d}$ - state of research on the evolution of technical thinking of youth. Development of the technical thinking is one of the objectives in the process of technical education. A picture taking part in it by building concepts and technical imagination fulfilling a significant role in the illustration and understanding of issues and technical products and the specific technical action. Technical education requires from teachers to enter a wide range of activities in the teaching process in the direction of the effective application and the use of image in the development of technical thinking and imagination of students. Pictures have a prominent role here.
\end{abstract}

Keywords: education, technical thinking, technical training.

\section{"SPEECH" OF THE IMAGE}

Direct sensory experience consists of abstract sensations, for each visible image. A human is the only being who perpetuates things visually and has a meaning for them. When any of these items is restrict or even completely eliminate, it brings to the impoverishment of communication. Metaphorical image and essence consist in putting a particular subject in a particular material using a mold, which not only serves as a measure of representation, but also retains some value independently and is subject to its own laws.

An image, according to its genus and species, comprises a layer of sensory experience, which appears on the background layer of meaning. If it has some content it may appear in the ideas that are usually carried of particular momentous of human values. We mean a layer of appearance, sensory perceptions, and meanings. In terms of aesthetics, there are three systems of representa- tion because of the perception: representation of the iconic, symbolic and enactive. The first representation arises as a result of "selective organization insights and perceptions in terms of time and space", and creates a "pictorial equivalent of things and events". Symbolic representation subordinates these images' representation of the world through a linguistic code. Language code is a "way of creating experiences and transform it". The result of this translation is an enactive representation, which allows you to define events through patterns of actions that cause it, other owls is a bridge that transition from knowledge to action [11].

Psychology refers to aesthetic experiences as those reflecting feelings and attitude to objects, situations and processes, which primary feature the beauty and property. The aesthetic emotions are triggered by the beauty of nature, architecture, man, but also for many everyday objects that "suddenly and unexpectedly reveal its beauty" 
[10]. The aesthetic experience according to this definition is associated with a spontaneous reaction, which is not due to the competence of the object as experienced, is the emotional expression of admiration for its unique beauty.

For specific feature of the aesthetic experiences are considered portraying things unique, concealed, unknown or unusual experienced in special emotional stress. Particularly active in the sense of illumination is a sight. Floodlights survival has a physical basis, occurring with the beauty of nature, the beauty of man or works of such, for example art or technique. In the experience caused by illumination comes to the perception of new properties of things and seeing them in a new light. Novelty of these observations makes the vision continues for some time even after the resignation of incentives that stimulate the senses. This is the time in which the entity caused the need to understand their meanings, intensely guess rediscovered meanings in reflective activity [7].

Pedagogy contrast uses the aesthetic experiences in implementing many of its educational goals. The effect of parental or educational image is dependent on the intensity of personal experience, energized by a certain type of experience or action. This experience is not limited to a passive perception, it must be an expression of a deeper, include the contents of human experience [14].

In the process of image perception the aesthetic experience is very important having the character of personal experience. The fact that each image can interact aesthetically, is due to human imagination. If something has to work it must be made knowingly, with the intent to act in a certain way to imagination and guided people in a new direction [7].

A characteristic feature of the image is a kind of speech quality, under which the entire contents of the work fully and explicitly included in a specially shaped mold. Picture, although shows us a known world, it affects the recipient differently than in real life. Its qualitative expression forces reflection and makes us see previously invisible relevant aspects.

For the picture to be clear and have an educational need, it is important to be accessible accessible. Generally speaking, the sharing of works can be reduced to three methods. The first consists in communicating their own experience and aesthetic judgment to others on the unwitting recipient of a joint analysis of the structure of the work, the administration of its explanations of the history of art and the exchange of feelings and sensations associated with the reception of the image. The second method is to create people who have this passion and predisposition conditions to create their own forms of imaging techniques (drawing, painting, video, etc...), which is exploring the nature and shape of the pieces by their own artistic activity. And the third method is to study the development of contemporary visual culture, participating in exhibitions, events or performance, the subject and object is the body of the performer in a specific context of time, space and their own limitations. Educational activities undertaken within making accessible arts are essential to the effectiveness of education through art image.

Modern man is different than a man of previous eras. Mass media and the development of new technologies have blurred the difference between the natural world and the world of illusion,; men lives among the images they created, at least at this stage, what in the world of nature. This entails the danger of moving into the world of images without checking whether or not we can understand that world which is created just for the recipient. Therefore, the duty of the educator is to adapt the process of education according to the principle of gradation of difficulty with the help of images. At the very beginning there were feelings of affirming the established order of the world, in all aesthetic, moral, and cognitive terms. Only when the recipient is mature enough to understand more complex representations of reality, we can turn on the educational process work harder in perception, images that raise questions, express concerns, and show the drama of human life [15].

\section{THE IMAGE AS AN EDUCATIONAL TOOL}

Culture of the image especially in today's media suggests that we live in a world dominated by the transfer of information through images. The image plays an increasingly important role in the transmission of a variety of content; it is an integral part of telegrams with layers of linguistic and nonlinguistic, which implies acceptance of it as a very important means of communication [13]. The image is one of the most natural remedies which we refer to when we experience difficulties in receiving, understanding and assimilation 
of verbal information. The easiness of transition from one code to another, and their complementarily demonstrates the positive role of the image in learning verbal material.

The image in education is part of a set of tools for supporting teaching and education, and improves work efficiency. The role of technology in the education process and the challenges around us actually cause the need for more dynamic processes of adapting the education system to the needs posed especially by civilization and modern information society. Thanks to information technology, an image became the main carrier of information and communication as well as a tool for learning and student's intellectual work. Hence, the formation of the information age implies a change in the teaching and implementation of the educational process [5].

Various technical means and technologies are used to optimize educational processes. Computer-aided teaching, which is in fact based on images, has become a reality. Computer and the Internet are two basic passwords and directions of the contemporary use of information technology in education. We should pay attention to the infrastructure supporting science and the potential of information technology for use in the modern school. Materials and visual texts can be regarded as an important part of the education process, as they provide both existing communication standards, shaping attitudes towards the objects of the social world and the physical, aesthetic sensitivity affect consumers and become the basis for constructing collective representations of reality and their naturalization as the only and validated by knowledge of the world [9].

Information technology, information, communication and media used in education consist of educational technology. Largely based on the image, they create conditions for learners to build knowledge and provide a set of cognitive tools. Illustration arouses feelings of aesthetic, curious, easily introduces the topic, and makes learning more enjoyable [1]. The aim of education should be creating a model of education that will allow the young receiver function iconosphere. The inclusion in the model complex relationships between word and image in the communications of various functions, various images and discourses is essential.

Because of its common receiving widespread superficial attention to reading the information, without having to be in the relationship between the objects placed on the transmission of pictorial, without taking into account the structure of the verbal acceptance - imaging, without reflection on the deeper meaning of speech.

\section{THE ESSENCE OF THE TECHNICAL THINKING}

The technical thinking as an intellectual process is conceptually-imaginative [3]. Thinking is a process integrated conceptually, based on the material-pictorial, and not only pictorial or conceptual layer, although the conceptual component and the imaginary component is involved in the thought process, and sometimes emphasizes one or the other aspect that sets the tone for the whole thinking or phase [6]. The role of the imagination in the process of understanding in terms of technical products used in those rights and principles is significant. Comprehension is an aspect of the technical thinking and the guarantor of success in technical action [3]. Technical action creates a large number of situations that modify the course and structure of thinking while solving specific tasks. We can also indicate the variety and types of thought process: theoretical and practical thinking, concrete and abstract, reconstructive and creative.

The technical thinking, due to the particularity of the object of thought allows extracting typical types:

- practical thinking, in which mental operations take place in the course of action on the real object;

- graphic thinking (drawing- technical) in which mental operations take place on the basis of a graphic image of the technical structure;

- imaginative thinking, in which mental operations take place entirely in the plane of imagination and rely on imaginative representation of technical structures;

- conceptual thinking, in which the base for mental operations are primarily words and descriptions [3].

These types of the technical thinking are merely intellectual diversity of operations when solving specific technical tasks. They are characterized by a hierarchy of abstractness. The first step is the drawing and the related graphical thinking, the second stage is based on imaginative thinking 
patterns, and third grade is conceptual thinking imaginatively based on models - conceptual. All of them are intertwined when thinking in terms of technical precision in the creative process. Components of thinking include: knowledge, experience and aptitude, and these are associated with specific person.

Thus, the development of technical thinking in the first place needs to be personalities to shape the student. In the process of personality formation, it is essential to pay attention to:

- shaping research attitudes - seeking qualities of things, activities, and events, while waking interests of the society, nature and technology;

- shaping diagnostic attitudes - identifying the causes of the effects observed, and analyze properties and values of things, actions and phenomena;

- shaping organization attitudes - self-organization of the executive work;

- development of creative attitude - to show creativity in solving problems in the operation;

- shaping the moral and social attitude - an element of the whole, which is the collective tion;

Students learn to behave responsibly in ac-

- shaping the aesthetic attitude - it develops when students keep order in the workplace, respect the order of behavioral operations, care about the figment aesthetics.

These tasks and tasks of the technical thinking draw attention to the functions of the image in the educational process. Pilot studies among students of Lublin Technology University indicate the importance of image in the educational process, especially the media materials (and visuals).

\section{IMAGE FUNCTIONS IN THE LEARNING PROCESS}

From the literature we know that visuals and especially the media have a variety of impacts on students $[2,12]$. Preliminary studies conducted among the students of the Technical University of Lublin suggests that in the process of the technical thinking students can indicate cognitive function, activating information and practical visual materials.

\section{Cognitive function}

It is to bring the learner to the analyzed reality. It occurs during the process of learning and memorizing the learning material for synthetic imaging and sound representation of the subject matter. The use of an appropriate image, which forces to think and search for solutions, improves the quality, speed and accuracy of remembering the contents. It helps to extract and organize messages more accurately and effectively apply them in practice.

\section{The information function}

This feature is reflected in the rapid and accurate transmission of messages through images. Information which is provided in a multi sensory manner is easier and more durably adopted by the students. Showing the application of laws and theories in practice, patterns, implementation of technical activities is expected by students.

\section{The activating function}

This function is activating learning through curiosity and interest. Moreover, it has an influence on the development of perception, imagination and triggers thought processes. The use of the device and media content at the right time of the learning process gives a keen interest in the subject of knowledge, implies a positive motives and curiosity and the desire and willingness to learn about technical issues.

\section{The practical}

Many types of teaching materials used in the educational process of students affect opinion and encourage the search for practical solutions and applications, and the ability to think creatively. The use of images makes it easy to reference and comment on the specific technical situation, it is helpful during observations and exercises conducted in the studios, performed work and professional practice.

Isolated above features are essential for the respondents. Preliminary studies indicate the use of the image in the learning process is highly required. In the process of forming an image meets the technical thinking - a basic function, an open issue is the practical use and teaching implications. 


\section{CONCLUSIONS}

Shaping the technical thinking is a complex issue. In the process the image takes part in building concepts and ideas.. In students' opinions images play primarily the following functions: cognitive, information, activating and practical. Theoretical and practical approach requires their use in the learning process, so as to assist the student in technical thinking.

An important issue is the development of the use of the image projected achievements in shaping the technical thinking and methods of measurement. One of the tasks is to prepare teachers towards effective application and the use of image. Therefore, the task of the University is to provide necessary materials, aids and equipment. Adoption of the above tasks will allow teachers to have more effective educational work.

The undertaken research does not close the research field. It opens the possibility of testing for, barriers and effects of shaping technical thinking of students and the use of video as a teaching oriented towards post conventional level.

\section{REFERENCES}

1. Arnheim R.: Sztuka i percepcja wzrokowa. SłowoObraz-Terytoria, Gdańsk 2005.
2. Berezowski E., Długoszowa J.: Techniczne środki nauczania. Warszawa 1973.

3. Franus E.: Myślenie techniczne. Wrocław-Warszawa-Kraków-Gdańsk 1978.

4. Furmanek W.: Jutro edukacji technicznej. Rzeszów 2007.

5. Gejdoš M.: Kultura szkoły jako wartość szkolnej wspólnoty. [W:] Zborník materiálov z medzinárodnej vedeckej konferencie. Češrnivci. Zelena Bukovina 2008.

6. Gejdoš M.: Vplyv prostredia výchovy na integrálny rozvoj diet'at'a. [In:\} Dialog Europa XXI, 16 (34), 2006.

7. Lach-Rosocha: Pedagogika przeżycia estetycznego. Wychowanie człowieka jako osoby. Kraków 2003, 88-89.

8. Nazar J.: Kształtowanie zainteresowań technicznych dzieci i młodzieży. Warszawa 1975.

9. Ogonowska A.: Przemoc ikoniczna. Kraków 2004.

10. Przetacznikowa M., Makiełło-Jarża G.: Psychologia ogólna. Warszawa 1975.

11. Siuta J. (red.): Słownik psychologii. Kraków 2005.

12. Strykowski W.: Audiowizualne materiały dydaktyczne. Warszawa 1984.

13. Tomaszkiewicz T.: Przekład audiowizualny, Warszawa 2006.

14. Wojnar I.: Sztuka i wychowanie. [W:] W. Szewczuk (red.), Encyklopedia psychologii. Warszawa 1998, p. 806.

15. Wojnar I.: Teoria przeżycia estetycznego. Zarys problematyki. Warszawa 1995. 